\title{
PENGARUH BUDAYA ORGANISASI, KECERDASAN SPRITUAL DAN MOTIVASI TERHADAP KINERJA DAN KEPUASAN KERJA KARYAWAN PADA PT PELINDO IV (PERSERO) DI MAKASSAR
}

\author{
Oleh: \\ Verri Ginoga \\ Sekolah Tinggi Ilmu Ekonomi Lamappapoleonro Soppeng \\ Email : \\ verri_2011@yahoo.co.id
}

\begin{abstract}
ABSTRAK
Penelitian ini dilakukan bertujuan untuk: (1). Menguji dan menganalisis pengaruh Budaya Organisasi terhadap Kinerja Karyawan, (2). Menguji dan Menganalisis Pengaruh Kecerdasan Spiritual terhadap Kinerja Karyawan, (3). Menguji dan Menganalisis Pengaruh Motivasi terhadap Kinerja Karyawan, (4).Menguji dan Menganalisis Pengaruh Budaya Organisasi terhadap Kepuasan Kerja Karyawan, (5). Menguji dan Menganalisis Pengaruh Kecerdasan Spiritual terhadap Kepuasan Kerja Karyawan, (6). Menguji dan Menganalisis Pengaruh Motivasi terhadap Kepuasan Kerja Karyawan, (7). Menguji dan Menganalisis Pengaruh Kinerja terhadap Kepuasan Kerja Karyawan. Penelitian ini menggunakan data primer melalui survey sebanyak 215 orang sampeldaripopulasijumlahkaryawansebanyak477 orang. Data analisis menggunakan program Structural Equation Modeling (SEM). Hasil Peneltian ini menunjukan bahwa; (1). Variabel kecerdasan spiritual tidak berpengaruh signifikan terhadap variable kepuasan kerja (job satisfaction), berdasarkan hasil survey yang sangat berpengaruh terhadap kepuasan kerja (job satisfaction). (2). Variabel budaya organisasi berpengaruh positif signifikan terhadap kinerja dan kepuasan kerja (job satisfaction). (3). Variabel kecerdasan spiritual berpengaruh positif signifikan terhadap variabel kinerja. (4). Variabel motivasi berpengaruh positif signifikan terhadap kinerja dan kepuasan kerja (job satisfaction). (5). Terdapat pengaruh signifikan positif variable kinerja terhadap Kepuasan kerja (job satisfaction). Diantara variabel variabel yang yang ada ternyata budaya organisasi sangat signifikan mempengaruhi kinerja dan kepuasan kerja (job satisfaction), Di samping itu melalui peningkatan kecerdasan spiritual dapat menumbulkan perilaku positif berupa ketaatan terhadap peraturan, ketaatan terhadap etika moral, jujur, terbuka, amanah, sopan dan toleran terhadap sesama, akan berdampak pada penerapan Program Tata Kelola Perusahan yang Baik (good corporate governance).

Kata Kunci: Budaya Organisasi, Kecerdasan Spiritual, Motivasi, Kinerja dan Kepuasan Kerja
\end{abstract}




\section{A. PENDAHULUAN}

Era globalisasi yang dimulai pada abad ke-21, merupakan era persaingan SDM antar bangsa. Kualitas SDM itu sendiri meliputi; kualitas moral, Spritual, intelektual dan kualitas fisik sehingga mampu menghadapi tantangan masa depan. (Rivai, 2005). Aset ekonomi semakin tidak bersifat fisik, seperti gedung, mesin, properti lainnya, tetapi bersifat mental intelektual, seperti persepsi pasar, hubungan, citra perusahaan, citra merek, hak paten, kredibilitas, visi, dan pengetahuan khusus (Senamo, 2002, dalam (Sutrisno, 2010). Untuk hal tersebut dibutuhkan (SDM) yang memiliki akal dan perasaan, keinginan, ketrampilan, pengetahuan, dorongan, daya dan karya (rasio, rasa dan karsa). Semua potensi sumber daya tersebut berpengaruh terhadap upaya organisasi dalam mencapai tujuan. Werther dan Davis (1996), dalam (Sutrisno, 2010); menyatakan bahwa (SDM) adalah; pegawai yang siap, mampu dan siaga dalam mencapai tujuan-tujuan organisasi'. Sebagaimana dikemukakan bahwa dimensi pokok sisi (SDM) adalah kontribusinya terhadap organisasi, sedangkan dimensi pokok manusia adalah perlakuan kontribusi terhadapnya yang pada gilirannya akan menentukan kualitas dan kapabilitas hidupnya.

Penilaian sebuah organisasi atau perusahaan merupakan sebuah proses formal untuk melakukan peninjauan kembali dan evaluasi prestasi kerja seorang secara periodik. Kegiatan itu terdiri dari identifikasi, observasi, pengukuran dan pengembangan hasil kerja karyawan dalam sebuah organisasi. Pada umumnya kinerja perusahaan diukur dari aspek keuangan dan operasional. Sedangkan kinerja karyawan dapat diukur melalui performance appraisal (Rivai, 2005). Karyawan sebagai petugas pelaksana lapang harus memiliki suatu komitmen keorganisasian yang kuat, karena komitmen tersebutmerupakan prinsip dan budaya yang fundamental bagi keberhasilan organisasi.(Keith \& Newstrom, 1990). Disamping komitmen terhadap organisasi, karyawan juga harus memiliki motivasi kerja yang tinggi dan terpelihara, karena motivasi sangat terkait dengan kepuasan kerja setiap karyawan dari level terendah sampai pada level tertinggi.

PT Pelindo IV sebagai objek penelitian dituntut untuk menyusun rencana yang strategis dan rencana korporasi di segala bidang. Sebagai salah satu pelaku ekonomi di sektor jasa kepelabuhan yang akhir-akhir ini sering mendapat sorotan dari berbagai pihak dalam negeri maupun luar negeri, maka perlu melakukan upaya dengan konsep, melakukan pengelolaan pelabuhan secara terintegrasi dengan kewirausahaan yang berasaskan Konsep Nilai Perusahaan yakni, Profesionalisme, Kerjasama Tim, Kreativitas, Kejujuran serta integritas secara luas dan berkeninambungan. Adapun bentuk kegiatan PT Pelindo IV adalah untuk kelancaran mobilisasi transportasi laut dan peti kemas. (posted, admin by internet PT Pelindo IV, 2015)

Dengan adanya era globalisasi yang dewasa ini menjadi isu internasional maka, perusahaan perlu melakukan perubahan perubahan kearah yang lebih professional baik dari sistem pengelolaan serta penyediaan karyawan yang professional pula. Cooper dan Sawaf (2000) dalam (Boy, 2009); menyatakan bahwa kontribusi IQ terhadap keberhasilan seseorang dalam dunia nyata hanya menyumbang 
$4 \%$ dan lebih dari $90 \%$ keberhasilan kemungkinan ditentukan oleh kecerdasan lain, salah satunya adalah kecerdasan spiritual. Sehingga karyawan perlu mengembangkan dirinya melalui kecerdasan spiritual yang dapat menunjang dirinya dalam melaksanakan tugasnya dengan baik.

Kecerdasan spiritual memberi kita rasa moral, kemampuan menyesuaikan aturan yang kaku, dibarengi dengan pemahaman dan cinta serta kemampuan setara untuk melihat kapan cinta dan pemahaman sampai pada batasannya. Kita menggunakan kecerdasan spiritual untuk bergulat dengan ihwal baik dan jahat, serta untuk membayangkan kemungkinan yang belum terwujud untuk bermimpi, bercitacita, dan mengangkat diri kita dari kerendahan. Sinotar (2001) dalam (Duta, 2010) mendefinisikan kecerdasan spiritual sebagai pemikiran yang terilhami. Agustian (2001) dalam (Duta, 2010) kecerdasan spiritual adalah kemampuan untuk memberi makna ibadah terhadap setiap perilaku dan kegiatan, melalui langkah-langkah dan pemikiran yang bersifat fitrah, menuju manusia yang seutuhnya (hanif) dan memiliki pola pemikiran tauhidi (integralistik) serta berprinsip hanya kepada Allah. Kecerdasan spiritual ini sangat di perlukan oleh setiap karyawan PT Pelindo IV, agar budaya perusahan yakni jujur dan ikhlas bekerja dapat tercapai .(Sumber; budaya PT Pelindo IV).

Selain itu, terdapat juga motivasi kerja, karena motivasi mempunyai kaitan dengan suatu proses yang membangun dan memelihara perilaku kearah suatu tujuan. (Jonnes, 1997) dalam (Class, 2010). Motivasi mempersoalkan bagaimana mendorong gairah kerja bawahan, agar mereka mau bekerja keras dengan memberikan semua kemampuan dan ketrampilannya untuk mewujudkan tujuan perusahaan. Salah satu upaya PT Pelindo IV untuk meningkatkan mutu dan kwalitas kerja karyawan adalah dengan memberikan motivasi kerja yang berkesinambungan, konsisten, penghargaan, funishment dan penilaian kinerja terhadap setiap karyawan mulai dari level tertinggi sampai level terendah. Dengan demikian diharapkan tercapailah Visi dan Misi PT Pelindo IV, dari aspek ekonomiyaitu :

Visi : Menjadi Perusahaan yang bernilai dan berbudaya tarik tinggi melalui proses dan pelayanan unggul dengan orang - orang bahagia

Misi 1). Menjadi penggerak dan pendorong pertumbuhan ekonomi Indonesia Tengah dan Timur. 2). Memberikan tingkat kepuasan pelanggan yang tinggi. 3). Tingkat kepuasan dan ketertarikan pegwai terus meningkat. 4). Menjadi mitra usaha yang terpercaya dan menguntungkan, pertumbuhan pendapatan dan laba usaha 20 persen setiap tahun. 5). Menjadi publik company tahun 2018.

Berdasarkan uraian-uraian diatas, maka tujuan penelitian ini adalah untuk menganalisis pengaruh Budaya Organisasi terhadap Kinerja PT Pelindo IV, menganalisis pengaruh Kecerdasan Spiritual terhadap Kinerja PT Pelindo IV, menganalisis pengaruh Motivasi terhadap Kinerja PT Pelindo IV, menganalisis pengaruh Kecerdasan Spiritual terhadap Kinerja PT Pelindo IV, menganalisis pengaruh Motivasi terhadap Kepuasan kerja karyawan PT Pelindo IV, menganalisis pengaruh Budaya organisasi terhadap Kepuasan kerja karyawan PT Pelindo IV, 
mengnalisis pengaruh Kinerja karyawan terhadap Kepuasan kerja karyawan PT Pelindo IV.

\section{B. KAJIAN PUSTAKA}

Kerangka pemikiran tentang PengaruhBudaya Organisasi, Kecerdasan Spiritual dan Motivasiterhadap Kinerja karyawan dan Kepuasan kerja sebagaimana pada Gambar 1 dibawah ini:

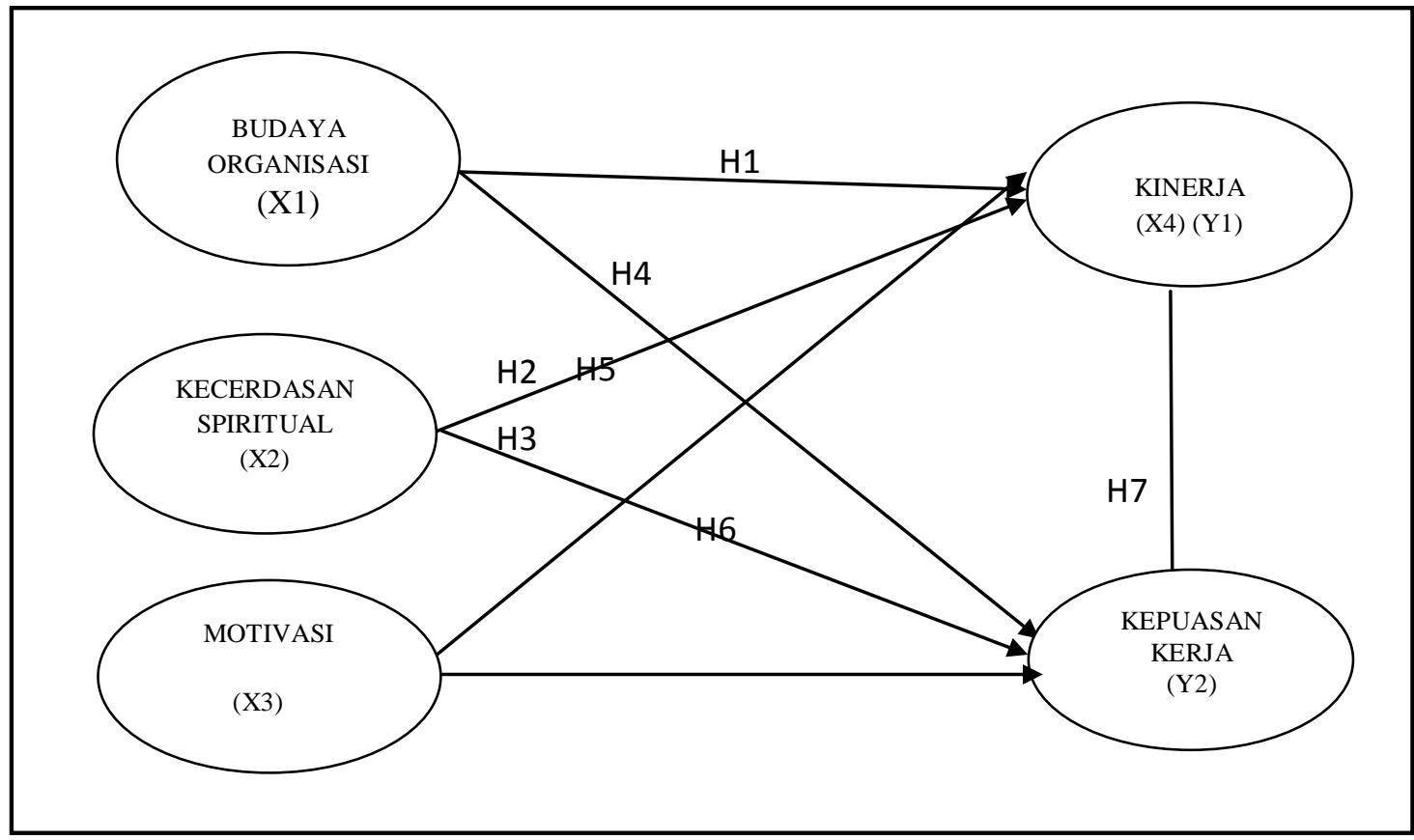

Gambar 1. Hipotesis Penelitian

Dimana H1: budaya organisasi berpengaruh terhadap kinerja karyawan. H2 kecerdasan spiritual berpengaruh terhadap kinerja. H3. Motivasi berpengaruh terhadap kinerja. H4. Budaya organisasi berpengaruh terhadap kepuasan kerja. H5. Kecerdasan spiritual berpengaruh terhadap kepuasan kerja. H6. Motivasi berpengaruh terhadap kinerja. Dan H7. Kinerja berpengaruh tehadap kepuasan kerja..

\section{METODE PENELITIAN}

Penelitian ini bersifat verifikatif dan melihat pengaruh yang bertujuan untuk memperoleh deskripsi tentang ciri-ciri variabel budaya organisasi, motivasi dan kecerdasan spiritual terhadap kinerja dan kepuasan kerja Karyawan PT Pelindo IV. Sifat penelitian verivikatif pada dasarnya ingin menguji kebenaran dari suatu hipotesis yang dilaksanakan melalui pengumpulan data di lapangan. Penelitian ini 
dilaksanakan pada PT Pelindo IV (Persero) di Makassar. Dalam penelitian ini diperlukan berbagai data, antara lain data primer berupa kuesioner yang dibagikan kepada setiap responden. Kemudian data sekunder yang diperoleh dari lembaga yang terkait, dokumentasi dan hasil penelitian yang relevan dengan variabel yang diteliti dan relevan dengan perusahaan yang diteliti.

Teknik pengumpulan data dalam penelitian ini dilakukan dalam beberapa proses, yakni: 1). Wawancara langsung yaitu dilakukan kepada pegawai perusahaan yang dijadikan responden. 2). Observasi dimaksudkan untuk mencari data melalui pengamatan peneliti terhadap kegiatan pegawai perusahaan. 3). Kuesioner dilakukan dengan cara membuat daftar pertanyaan yang dilengkapi dengan alternatif jawaban dan kemudian di bagikan kepada responden. 4). Dokumentasi. Sedangkan untuk populasi dalam penelitian ini adalah seluruh karyawan PT Pelindo IV (Persero) di Makassar,berdasarkan strata jabatan mulai dari General Manager/Senior Manajer sampaistaff pelaksana yang berjumlah 477 orang. Pengambilan data, karyawan dari level General Manager/Senior Manajer sampai pada staf dilakukan sensus secara proposional. Jumlah sampel adalah45 \% dari jumlah populasi yang(Arikunto, 1998)

Metode analisis data yang dilakukan dimulai dengan uji model dengan Structural Equation Modeling (SEM). Metode SEM ini akan memudahkan analisis secara simultan, lebih ringkas, dan efisien.Setelah model tersebut memenuhi syarat, selanjutnya adalah uji regression weight/loading factor. Uji ini dilakukan sama dengan uji t terhadap resession weight / loading factor / koefesien $\lambda$. Uji ini untuk menolak hipotesis nol yakni koefesien $\lambda_{1}=0$ (yakni ; bobot regresi variabel laten dengan variable observer tidak diterima atau bobot regresi variabel independen dengan variabel dependen tidak diterima.

Pokok masalah yang diteliti bersumber pada 3 hal yaitu faktor budaya organisasi, kecerdasan spiritual dan motivasi sebagai veriabel bebas (variabel $\mathrm{x}$ ), kinerja dan kepuasan kerja karyawan sebagai variabel tidak bebas/terikat (variabel y). Untuk validitas data terkait kuesioner penelitian ini terbentuk dari tiga konsep teoritis. Konsep-konsep tersebut adalah Pengtahuan TI, dukungan teknis, kemudahan menggunakan TI, computer self-efficacy, harapan hasil, komitmen dan kinerja. Sebuah konsep tersusun dari beberapa komponen atau variabel. Bila pada uji validitas ditemukan sebuah komponen tersebut tidak konsisiten dengan komponen-komponen lain untuk mendukung sebuah konsep. Sedangkan untuk uji reliabilitas instrument penelitian ini menghasilkan alpha yang telah di bakukan (standardized item alpha) dan nilai alpha ini harus lebih besar dari reliabilitas yang diinginkan. Instrumen dapat dikatakan andal (reliable) jika memilki koefesien keandalan reliabilitas sebesar 0,6 atau lebih (Arikunto, 1998); Untuk memudahkan dan mempercepat perhitungan dalam penelitian ini, peneliti menguji reliabilitas dengan SPSS. Serta uji instrument dilakukan terhadap 30 responden, yaitu karyawan PT Pelindo I, dimana karyawan yang telah menjadi responden dalam uji coba ini tidak diikutkan sebagai responden penelitian. Data hasil uji coba digunakan untuk pengujian validitas dan reliabilitas instrument. Proses perhitungan dilakukan dengan SPSS. 


\section{HASIL DAN PEMBAHASAN}

\section{Hasil Pengukuran Variabel Laten Budaya Organisasi, Kecerdasan Spiritual, dan Motivasi}

Model pengukuran budaya organisasi, kecerdasan spiritual dan motivasi maka kriteria model telah menunjukkan adanya model fit atau kesesuaian antara data dengan model. Hal ini dibuktikan dari delapan criteria fix yang ada, semuanya telah memenuhi kriteria. Dengan demikian model di atas menunjukkan tingkat penerimaan yang baik oleh karena itu dapat disimpulkan bahwa model dapat diterima. Kemudian Loading faktor $(\lambda)$ pengukuran variabel budaya organisasi, kecerdasan spiritual dan motivasi menunjukkan hasil uji terhadap model pengukuran variabel budaya organisasi, kecerdasan spiritual dan motivasi dari setiap indikator yang menjelaskan konstruk, khususnya variabel laten (unobserved variabel), sehingga seluruh indikator diikutkan dalam pengujian berikutnya. Dari evaluasi model yang diajukan menunjukkan bahwa evaluasi terhadap konstruk secara keseluruhan menghasilkan nilai di atas kritis yang menunjukkan bahwa model telah sesuai dengan data, sehingga dapat dilakukan uji kesesuaian model selanjutnya. Adapun pengolahan data selanjutnya menunjukkan bahwa model pengukuran kinerjadan kepuasan kerja maka kriteria model telah menunjukkan adanya model fit atau kesesuaian antara data dengan model. Hal ini dibuktikan dari delapan criteria fix yang ada, semuatelah memenuhi criteria. Dengan demikian model di atas menunjukkan tingkat penerimaan yang baik oleh karena itu dapat disimpulkan bahwa model dapat diterima.Selanjutnya untuk mengetahui variabel yang dapat digunakan sebagai indikator dari kinerjadan kepuasan kerja dapat diamati dari nilai loading faktor atau koefisien lambda $(\lambda)$ dan tingkat signifikansinya, yang mencerminkan masing-masing variabel sebagai indikator kinerjadan kepuasan kerja dari hal itu terlihat loading faktor $(\lambda)$ pengukuran variabel kinerjadan kepuasan kerja menghaslkan uji terhadap model pengukuran variabel kinerjadan kepuasan kerja dari setiap indikator yang menjelaskan konstruk, khususnya variabel laten (unobserved variabel), namun dari hasil analisi terlihat indikator Y1.4 memiliki nilai loading $<3$ yakni sebesar 0,240 sehingga indikator Y1.4 tidak diikutkan dalam pengujian berikutnya.

\section{Budaya Organisasi, Kecerdasan Spiritual, Motivasi, Kinerja dan Kepuasan Kerja}

Berdasarkan cara penentuan nilai dalam model, maka variabel pengujian model pertama ini dikelompokkan menjadi variabel eksogen (exogenous variabel) dan variabel endogen (endogenous variable). Variabel eksogen adalah variabel yang nilainya ditentukan di luar model. Sedangkan variabel endogen adalah variabel yang nilainya ditentukan melalui persamaan atau dari model hubungan yang dibentuk. Termasuk dalam kelompok variabel eksogen adalah pengukuran budaya organisasi, kecerdasan spiritual dan motivasi sedangkan yang tergolong variabel endogen adalah kinerja. Dari evaluasi model menunjukkan dari delapan kriteria goodness of fit 
indices terlihat dari delapan kriteria yang diajukan hanya dua kriteria yang sudah memenuhi kriteria, sehingga dilakukan modifikasi model dengan melakukan korelasi antar error indikator sesuai dengan petunjuk dari modification indices. Hasil analisis setelah model akhir yang didapatkan adalah sebagai berikut bahwa evaluasi model menunjukkan dari delapan kriteria goodness of fitindice shanya satu yang belum memenuhi kriteria yakni AGFI namun nilainya sudah mendekati nilai kritis, sehingga model secara keseluruhan dapat dikatakan telah sesuai dengan data dan dapat dianalisis lebih lanjut.

Berdasarkan model empirik yang diajukan dalam penelitian ini dapat dilakukan pengujian terhadap hipotesis yang diajukan menlalui pengujian koefisien jalur pada model persamaan struktural. Dari keseluruhan model tujuh jalur yang dihipotesiskan, ada enam jalur yang signifikan dan satu jalur tidak signifikan. Adapun interpretasi pengolahan dapat dijelaskan sebagai berikut : 1) Budaya organisasi mempunyai pengaruh positif signifikan terhadap kinerja dengan $\mathrm{P}=0.000<0.05$ dengan nilai koefisien sebesar 0.558 , koefisien ini menunjukkan bahwa adanya budaya organisasi yang baik akan mendorong peningkatan kinerja karyawan. 2). Kecerdasan spiritual kerja mempunyai pengaruh signifikan terhadap kinerja dengan $\mathrm{P}=0.000<0.05$ dengan nilai koefisien sebesar 0.454 , koefisien ini menunjukkan bahwa semakin baik kecerdasan spiritual seorang karyawan maka kinerja akan semakin baik. 3). Motivasi pengaruh positifsignifikan terhadap Kinerja dengan $\mathrm{P}=0,048<0.05$ dengan nilai koefisien sebesar 0.154, koefisien ini menunjukkan bahwa semakin tinggi motivasi kerja seorang karyawan maka kinerja karyawan akan semakin baik pula. 4). Budaya organisasi mempunyai pengaruh positif signifikan terhadap kepuasan kerja dengan $\mathrm{P}$ $=0.000<0.05$ dengan nilai koefisien sebesar 0.583 , koefisien ini menunjukkan bahwa adanya budaya organisasi yang baik akan meningkatkan kepuasan kerja karyawan. 5). Kecerdasan spiritual kerja mempunyai pengaruh positif tidak signifikan terhadap kepuasan kerja dengan $\mathrm{P}=0.284>0.05$ dengan nilai koefisien sebesar 0.108, koefisien ini menunjukkan bahwa semakin tinggi kecerdasan spiritual karyawan maka kepuasan kerja akan semakin kecil. 6). Motivasi mempunyai pengaruh positif signifikan terhadap kepuasan kerja dengan $\mathrm{P}=0.045<0.05$ dengan nilai koefisien sebesar 0.274 , hal ini berarti bahwa motivasi kerja yang baik akan meningkatkan kepuasan kerja karyawan. 7). Kinerja mempunyai pengaruh positif signifikan terhadap kepuasan kerjadengan $\mathrm{P}=0.000<0.05$ dengan nilai koefisiensebesar 0.926, koefisien ini menunjukkan bahwa semakin baik kinerja seseorang maka kepuasan kerja karyawan akan semakin meningkat. Dan diketahui terdapat jalur yang pengaruh signifikan dan tidak signifikan.

Dengan demikian hipotesis: $\mathrm{H}_{1}$ : Budaya organisasi mempunyai pengaruh terhadap kinerja. $\mathrm{H}_{2}$ : Kecerdasan spiritual mempunyai pengaruh terhadap kinerja. $\mathrm{H}_{3}$ : Motivasi kerja mempunyai pengaruh terhadap kinerja. $\mathrm{H}_{4}$ : Budaya organisasi mempunyai pengaruh terhadap kepuasan kerja. $\mathrm{H}_{5}$ : Kecerdasan spiritual mempunyai pengaruh terhadap kepuasan kerja. $\mathrm{H}_{6}$ : Motivasi kerja mempunyai pengaruh terhadap kepuasan kerja. $\mathrm{H}_{7}$ : Kinerja mempunyai pengaruh terhadap kepuasan kerja. 


\section{Budaya Organisasi Berpengaruh Secara Signifikan terhadap Kinerja}

Menjawab rumusan masalah kesatu secara parsial dapat diamati dari hasil analisis SEM diketahui bahwa budaya organisasi berpengaruh signifikan terhadap kinerja. Hasil ini dibuktikan dengan adanya nilai t hitung (critical ratio) yang lebih besar dari t label dan nilai probability atau nilai $\mathrm{p}$ yang lebih kecil dari 0,05 . Penelitian ini juga menunjukkan adanya hubungan positif antara budaya organisasi dengan kinerja karyawan yang ditandai dengan koefisien jalur positif. Dengar demikian dapat disimpulkan bahwa budaya organisasi memberi peran terhadap kinerja karyawan. Artinya semakin kuat budaya organisasi kinerja karyawan semakin meningkat.

Berdasarkan hasil penelitian di lapangan diketahui pula bahwa factor budaya organisasi berada pada urutan pertama sedangkan motivasi berada pada urutan ketiga setelah kecerdasan spiritual. Dengan kata lain, elemen kompensasi tidak serta Marta dapat mempengaruhi kinerja karyawan. Variabel budaya organisasi yang dimaksud adalah orentasi pada prestasi dengan indicator bagaimana perusahaan mempengaruhi, mengatur dan mengarahkan karyawan di PT Pelindo IV Makassar. Efek langsung budaya organisasi terhadap kinerja karyawan dengan arah positif sebesar 3,725, efek tidak langsung nya sebesar 0,000 , dan efek total yang merupakan penjumlahan efek langsung dan efek tidak langsung sebesar 3,725. Dengan demikian dapat disimpulkan bahwa H1, yang menyatakan bahwa motivasi berpengaruh signifikan terhadap kinerja terbukti atau didukung fakta.

\section{Kecerdasan Spiritual Berpengaruh Secara Signifikan terhadap Kinerja}

Dari analisis data yang dilakukan, diketahui bahwa kecerdasan spiritual berpengaruh signifikan terhadap kinerja. Hasil ini dibuktikan dengan adanya nilai $\mathrm{t}$ hitung (critical ratio) yang lebih besar dari t tabel dan nilai probability atau nilai $\mathrm{p}$ yang lebih kecil dari 0,05 . Penelitian ini juga menunjukkan adanya hubungan positif antara kecerdasan spiritual dengan kinerja yang ditandai dengan koefisien jalur positif. Dengar demikian dapat disimpulkan bahwa kecerdasan spiritual memberi peran terhadap performance appraisal artinya semakin tinggi kecerdasan spiritual yang ada dalam diri seseorang akan semakin meningkatkan kinerja karyawan.Berdasarkan hasil penelitian di lapangan diketahui pula bahwa indikator pengetahuan diri yang dimiliki oleh karyawan berada pada urutan yang paling tinggi dan disusul dengan spiritual non-dogmatis dan selanjutnya disusul oleh variabel lain.Artinya adalah elemen pengetahuan diri, ilmu pengetahuan dan keterbukaan serta kejujuran dapat mempengaruhi kinerja karyawan. PT Pelindo IV Makassar. Dan menunjukkan efek langsung kecerdasan spiritual terhadap kinerja karyawan dengan arah positif sebesar 3,581, efek tidak langsung nya sebesar 0,000, dan efek total yang merupakan penjumlahan efek langsung dan efek tidak langsung sebesar 3,581. Dengan demikian dapat disimpulkan bahwa $\mathrm{H} 2$ yang menyatakan bahwa kecerdasan spiritual berpengaruh signifikan terhadap kinerja terbukti atau didukung fakta. 


\section{Motivasi Berpengaruh Signifikan terhadap Kinerja}

Diketahui bahwa motivasi berpengaruh signifikan terhadap kinerja. Hasil ini dibuktikan dengan adanya nilai t hitung (critical ratio) yang lebih besar dari t label dan nilai probability atau nilai $\mathrm{p}$ yang lebih kecil dari 0,05 . Penelitian ini juga menunjukkan adanya hubungan positif antara motivasi dengan kinerja karyawan yang ditandai dengan koefisien jalur positif. Dengar demikian dapat disimpulkan bahwa motivasi memberi peran terhadap performance appraisal. Artinya motivasi yang ada dalam diri seseorang akan semakin meningkatkan kinerja karyawan. Maksudnya adalah dengan karyawan yang mempunyai motivasi yang tinggi untuk menyelesaikan suatu tugas atau tanggung jawabnya, maka karyawan tersebut akan menghasilkan suatu performance atau kinerja yang baik pula sehingga nilai tambah untuk karyawan tersebut akan semakin meningkat.Berdasarkan hasil penelitian di lapangan diketahui pula bahwa indikator penghargaan atas imbalan yang diterima karyawan berada pada urutan kedua setelah penghargaan atas lingkungan. Dengan kata lain, elemen kompensasi tidak serta merta dapat mempengaruhi kinerja karyawan. Penghargaan atas lingkungan disini maksudnya adalah hubungan baik antar karyawan, sarana pendukung kerja, hubungan baik antar bidang dan tempat dimana karyawan bekerja di PT Pelindo IV Makassar. Adapun efek langsung motivasi terhadap kinerja karyawan dengan arah positif sebesar 2,014, efek tidak langsungnya sebesar 0,048, dan efek total yang merupakan penjumlahan efek langsung dan efek tidak langsung sebesar 2,014. Dengan demikian dapat disimpulkan bahwa H3, yang menyatakan bahwa motivasi berpengaruh signifikan terhadap kinerja terbukti atau didukung fakta.

\section{Budaya Organisasi Berpengaruh Secara Signifikan terhadap Kepuasan Kerja (Job Satisfaction)}

Diketahui bahwa budaya organisasi berpengaruh signifikan terhadap kepuasan kerja (job satisfaction). Hasil ini dibuktikan dengan adanya nilai t hitung (critical ratio) yang lebih besar dari t label dan nilai probability atau nilai $\mathrm{p}$ yang lebih kecil dari 0,05. Penelitian ini juga menunjukkan adanya hubungan positif antara budaya organisasi dengan kepuasan kerja (job satisfaction) karyawan yang ditandai dengan koefisien jalur positif. Dengar demikian dapat disimpulkan bahwa budaya organisasi memberi peran terhadap kepuasan kerja (job satis faction) karyawan. Artinya semakin kuat budaya organisasi kepuasan kerja (job satisfaction) semakin meningkat, Berdasarkan hasil penelitian di lapangan diketahui pula bahwa variabel budaya organisasi berada pada urutan pertama sedangkan motivasi berada pada urutan ke tiga setelah kecerdasan spiritual. Dengan kata lain, bahwa elemen kompensasi bukan merupakan faktor utama yang dapat mempengaruhi kepuasan kerja karyawan, namun variabel orientasi pada prestasi, orientasi pada kekuasaan, orientasi pada peran dan orientasi pada dukungan sangat mempengaruhi kepuasan kerja (job satisfaction)

karyawan di PT Pelindo IV Makassar. Adapun efek langsung budaya organisasi 
terhadap kinerja karyawan dengan arah positif sebesar 3,621, efek tidak langsung nya sebesar 0,000, dan efek total yang merupakan penjumlahan efek langsung dan efek tidak langsung sebesar 3,621. Dengan demikian dapat disimpulkan bahwa H4, yang menyatakan bahwa motivasi berpengaruh signifikan terhadap kinerja terbukti atau didukung fakta.

\section{Kecerdasan Spiritual Tidak Berpengaruh Secara Signifikan terhadap Kepuasan Kerja (Job Satifaction).}

Kecerdasan spiritual tidak berpengaruh signifikan terhadap kepuasan kerja (job satisfaction). Hasil ini dibuktikan dengan adanya nilai t hitung (critical ratio) yang lebih besar dari $\mathrm{t}$ tabel dan nilai probability atau nilai $\mathrm{p}$ lebih besar dari 0,05 . Penelitian ini juga menunjukkan adanya hubungan positif antara kecerdasan spiritual dan Kepuasan kerja yang ditandai dengan konsekwen jalur positif. Dengan demikian dapat disimpulkan bahwa kecerdasan spiritual member! peran langsung terhadap kepuasan kerja. Artinya apabila kecerdasan spiritual ditingkatkan maka kepuasan kerja (job satisfaction) akan meningkat pula. Disamping itu kecerdasan spiritual dapat menjadi alat ukur bagi manajemen dalam menempatkan karyawan pada jenjang karir yang sesuai dengan pengetahuan yang dimilikinya. Hasil penelitian di lapangan juga menunjukkan bahwa kecerdasan spiritual sangat mempengaruhi kinerja karyawan. Karena kecerdasan spiritual akan meningkatkan prestasi kerja, mengurangi stres bagi karyawan dan dapat menimbulkan semangat kerja. Seseorang yang membawa spiritualnya kedalam pekerjaannya maka dia akan merasakan bahwa makna pekerjaan dalam hidup sangat berarti, hal ini akan mendorong dan memotivasi dirinya untuk lebih meningkatkan kinerja yang dimilikinya sehingga melalui kinerja yang maksimal kepuasan kerja akan meningkat. Efek langsung kecerdasan spiritual terhadap kepuasan kerja dengan arah positif 1,071 efek tidak langsung nya juga bernilai dengan $r$ sama dengan 0.108 sedangkan efek total yang merupakan penjumlahan efek langsung dan efek tidak langsung sebesar 1,071. Dengan demikian dapat disimpulkan bahwa H5 yang menyatakan bahwa kecerdasan spiritual berpengaruh secara signifikan terhadap motivasi tidak terbukti atau tidak didukung fakta.

\section{Motivasi Berpengaruh Signifikan terhadap Kepuasan Kerja (Job Satisfaction)}

Motivasi berpengaruh signifikan terhadap kepuasan kerja (job satisfaction). Hasil ini dibuktikan dengan adanya nilai t hitung (critical ratio) yang lebih besar dari $\mathrm{t}$ tabel dan nilai probability atau nilai $\mathrm{p}$ yang lebih kecil dari 0,05 . Penelitian ini juga menunjukkan adanya hubungan positif antara motivasi dengan kepuasan kerja (job satisfaction) yang ditandai dengan koefisien jalur positif. Dengar demikian dapat disimpulkan bahwa motivasi memberi peran terhadap kepuasan kerja (job satisfaction). Artinya motivasi yang ada dalam diri seseorang akan semakin meningkatkan kepuasan kerja (job satisfaction) karyawan. Berdasarkan hasil penelitian di lapangan diketahui pula bahwa indikator penghargaan atas imbalan yang diterima karyawan berada pada urutan kedua setelah penghargaan atas 
lingkungan. Dengan kata lain, elemen kompensasi bukan faktor utama yang dapat mempengaruhi kepuasan kerja (job satisfaction). Penghargaan atas lingkungan disini maksudnya adalah hubungan baik antar karyawan, sarana pendukung kerja, hubungan baik antar bidang dan tempat dimana bekerja di PT Pelindo IV Makassar. Efek langsung motivasi terhadap kepuasan kerja (job satisfaction) dengan arah positif sebesar 2,061 efek tidak langsungnya sebesar 0,045, dan efek total yang merupakan penjumlahan efek langsung dan efek tidak langsung sebesar 2,061. Dengan demikian dapat disimpulkan bahwa H6, yang menyatakan bahwa motivasi berpengaruh signifikan terhadap kepuasan kerja (job satisfactyion) terbukti atau didukung fakta.

\section{Kinerja Berpengaruh Signifikan terhadap Kepuasan Kerja (Job Satisfaction).}

Kinerja berpengaruh signifikan terhadap job satisfaction. Hasil ini dibuktikan dengan adanya nilai $\mathrm{t}$ hitung (critical ratio) yang lebih besar dari t tabel dan probability atau nilai p yang lebih kecil dari 0,05 , Penelitian ini juga menunjukkan adanya hubungan positif antara kinerja dengan kepuasan kerja (job satisfaction) yang ditandai dengan koefisien jalur positif 2,807 dan $\mathrm{p}$ value 0.000. Dengan demikian dapat disimpulkan bahwa kinerja memberi peran langsung terhadap kepuasan kerja (job. Satisfaction); artinya karyawan yang mempunyai kinerja yang baik akan menghasilkan kepuasan kerja (job . satisfaction). Berdasarkan hasil penelitian di lapangan diketahui bahwa kepuasan kerja (job satisfaction) menunjukkan tingkat yang cukup signifikan terhadap kinerja karyawan. Ini tergambar dari kuatnya pengaruh indikator kinerja terhadap kepuasan kerja (job satisfaction) karyawan. Kepuasan kerja yang dihasilkan karyawan tidak terlepas dari penghargaan yang diberikan kepada karyawan apabila mereka menghasilkan suatu output yang berarti. Dengan tingkat kepuasan pekerjaan yang dirasakan oleh karyawan akan berdampak terhadap kinerja karyawan itu sendiri. Maksudnya disini adalah kepuasan dalam pekerjaan mempunyai arti bahwa kinerja karyawan baik, karena ini merupakan penghargaan terhadap hasil kerja yang ditunjukkan kepada perusahaan oleh karyawan yang bersangkutan. Efek langsung antara kinerja dan kepuasan kerja (job satisfaction) dengan arah positif sebesar 2.807 efek tidak berlangsung dengan nilai positif 0,000 , dan efek total yang merupakan penjumlahan efek langsung dan efek tidak langsung yang besarnya 2.807. Dengan demikian dapat disimpulkan bahwa H7, yang menyatakan bahwa kinerja berpengaruh signifikan terhadap kepuasan kerja (job satisfaction) terbukti atau didukung fakta.

Temuan teoritis dari penelitian ini berupa hubungan kausal antara kontrak atau variabel laten tersebut secara terperinci dapat dijelaskan sebahagian berikut: 1). Tidak terdapat pengaruh positif signifikan variabel kecerdasan spiritual terhadap kepuasan kerja (job satisfaction), Pengaruh positif ini berarti kecerdasan spiritual tidak berdampak pada kepuasan kerja (job satisfaction) secara langsung. 2). Terdapat pengaruh yang signifikan variabel budaya organisasi terhadap kinerja. Makin baik budaya organisasi maka karyawan semakin menunjukkan kinerja yang lebih baik pula. 3). Terdapat pengaruh positif signifikan variabel kecerdasan spiritual terhadap Kinerja. Pengaruh positif ini berarti kecerdasan spiritual berdampak pada kinerja 
karyawan. Dengan demikian semakin tinggi kecerdasan spiritual maka akan semakin baik pula kinerja karyawan. 4). Terdapat pengaruh positif signifikan variabel motivasi terhadap kinerja, Dengan demikian, semakin baik motivasi yang ada pada organisasi maka kinerja pun kian tinggi. 5). Terdapat pengaruh positif signifikan variabel budaya organisasi terhadap kepuasan kerja (job satisfaction), Dengan demikian, semakin baik budaya organisasi maka kepuasan kerja (job satifaction), akan semakin meningkat. 6). Terdapat pengaruh positif signifikan variabel motivasi terhadap kepuasan kerja (job satisfaction), Dengan demikian, semakin baik motivasi yang ada pada organisasi maka kepuasan kerja (job satisfaction) akan semakin tinggi. 7). Terdapat pengaruh signifikan positif variabel kinerja terhadap Kepuasan kerja (job satisfaction). Pengaruh signifikan ini berarti kinerja yang baik pada organisasi akan meningkatkan kepuasan kerja (jobsatisfaction)karyawan.

\section{E. SIMPULAN}

Berdasarkan hasil penelitian yang diperoleh bahwa hasil uji goodness of fit, diketahui bahwa model penelitian mempunyai kesesuaian yang baik dengan data. Ini ditunjukkan dengan nilai uji goodness of fit yang baik (memenuhi kriteria), walaupun berdasarkan analysis ada nilai goodness of fit yang belum memenuhi kriteria yakni GFI dan AGFI, namun hal ini bisa diterima karena GFI hanya merupakan analog dari $R$-Square yang berarti koefisien determinasi. Adapun hasil yang didapatkan adalah: 1). Variabel kecerdasan spiritual tidak berpengaruh signifikan terhadap variabel kepuasan kerja (job satisfaction), berdasarkan hasil survey yang sangat berpengaruh terhadap kepuasan kerja (job satisfaction) adalah pengetahuan diri berupa ilmu pengetahuan serta kejujuran akan sangat berpengaruh pada karyawan untuk bekerja dengan lebih baik. 2). Variabel budaya organisasi berpengaruh positif signifikan terhadap kinerja dan kepuasan kerja (job satisfaction), keberhasilan suatu perusahaan sangat ditentukan keberhasilannya dalam menciptakan budaya organisasi yang khas sebagai bagian dari rencana strategis setiap organisasi. Budaya organisasi yang efektif tersebut mencakup skala prioritas kegiatan, kriteria dalam penilain karyawan, perlakuan organisasi terhadap karyawan, bagaimana cara mengatur, mempengaruhi, dan mengarahkan karyawan, proses pengambilan keputusan, dasar penugasan yang jelas, perlu mempelajari hal-hal yang baru dalam perusahaan maupun di lingkungan sekitar perusahaan serta respon terhadap pengaruh lingkungan eksternal secara bersamaan berpengaruh signifikan terhadap kinerja dan kepuasan kerja (job satisfaction). 3). Variabel kecerdasan spiritual berpengaruh positif signifikan terhadap variabel kinerja karena hasil survei responden menyatakan bahwa melalui peningkatan kecerdasan spiritual akan dapat meningkatkan kinerja. Bahwa semakin tinggi tingkat kecerdasan spiritual seseorang maka akan semakin tinggi etika sosial yang tercermin dalam perilaku sesorang. Hal ini akan menimbulkan perilaku positif berupa ketaatan terhadap peraturan, ketaatan terhadap etika moral, jujur, dapat dipercaya (amanah), sopan dan toleran terhadap sesama karyawan serta mampu mengatasi setiap kesulitan dan penderitaan dalam pekerjaan. 4). Variabel motivasi 
berpengaruh positif signifikan terhadap kinerja dan kepuasan kerja ( job satisfaction), karena dengan motivasi berupa kompensasi dan penghargaan yang baik terhadap karyawan maka hal ini akan menjadi pendorong bagi karyawan untuk bertindak atau berprilaku dalam cara-cara tertentu untuk mencaapai keinginan atau harapannya yang akan berpengaruh pada kinerja dan kepuasan kerja (job satisfaction) Karyawan. 5). Terdapat pengaruh signifikan positif variabel kinerja terhadap Kepuasan kerja (job satisfaction). Pengaruh signifikan ini berarti kinerja yang baik pada organisasi akan meningkatkan kepuasan kerja (jobsatisfaction) karyawan

Hasil temuan penelitian yang menjadikannya berbeda dengan penelitian terdahulu antara lain adalah: 1). Diantara variabel variabel yang yang ada ternyata budaya organisasi sangat signifikan mempengaruhi kinerja dan kepuasan kerja (job satisfaction), artinya bahwa melalui budaya organisasi dapat diperoleh kinerja karyawan yang maksimal sehingga menghasilkan kepuasan kerja (job satisfaction) bagi karyawan. Melalui budaya organisasi ini juga karyawan dapat diberikan penghargaan dalam bentuk promosi, bonus ataupun hadiah, apabila karyawan melewati kriteria yang telah ditetapkan oleh perusahaan. Hal ini sekaligus akan menjadi motivasi bagi karyawan. 2). Melalui peningkatan kecerdasan spiritual dapat menumbuhkan perilaku positif berupa ketaatan terhadap peraturan, ketaatan terhadap etika moral, jujur, terbuka, amanah, sopan dan toleran terhadap sesama akan berdampak pada penerapan Program Tata Kelola Perusahan yang Baik (good corporate governance). 3). Variabel Kecerdasan Spiritual tidak berpengaruh signifikan terhadap kepuasan kerja namun melalui variable kinerja Kecerdasan Spiritual berpengaruh signifikan terhadap Kepuasan Kerja Karyawan.

Berdasarkan pembahasan sebelumnya, secara terperinci dapat dikemukakan saran-saran, baik untuk pengembangan pengetahuan maupun untuk kepentingan praktis. Adapun saran-saran yang dapat diajukan adalah: 1). Perlu diperhatikan variabel-variabel lain yang dapat meningkatkan motivasi maupun kinerja karyawan. .Keberhasilan didalam suatu organisasi tidak hanya ditentukan oleh variabel - variabel tertentu namun masih banyak variabel lain yang akan muncul seiring dengan perkembangan jaman disamping itu variabel akan berbeda di tempat yang berbeda. 2). Penelitian yang akan datang perlu memperluas obyek penelitiannya sehingga ada perbandingan faktor-faktor yang mempengaruhi kinerja dan kepuasan kerja (job satisfaction), terutama yang berhubungan dengan pemberian penghargaan terhadap karyawan yang mempunyai kinerja baik, 3). PT. Pelindo IV (Persero) perlu memperhatikan variabel variabel yang ada, terutama budaya organisasi sangat signifikan mempengaruhi kinerja dan kepuasan kerja (job satisfaction), artinya bahwa melalui budaya organisasi dapat diperoleh kinerja karyawan yang maksimal sehingga menghasilkan kepuasan kerja (job satisfaction) bagi karyawan. Melalui budaya organisasi ini juga karyawan dapat diberikan penghargaan dalam bentuk promosi, bonus ataupun hadiah, apabila karyawan telah melewati kriteria yang telah ditetapkan oleh perusahaan. Hal ini sekaligus akan menjadi motivasi bagi karyawan. 4). Program peningkatan kecerdasan spiritual perlu di rancang sebaik mungkin oleh karena semakin tinggi tingkat kecerdasan spiritual seseorang maka akan semakin 
tinggi etika sosial yang tercermin dalam perilaku sesorang. Hal ini akan menimbulkan perilaku positif berupa ketaatan terhadap peraturan, ketaatan terhadap etika moral, jujur, dapat dipercaya (amanah), sopan dan toleran serta mampu mengatasi kesulitan dan penderitaan dalam pekerjaan yang menjadi tugas dan tanggung jawabnya.

\section{DAFTAR PUSTAKA}

Arikunto, S. (1998). Prosedur Penelitian: Suatu Pendekatan Praktek (Revisi 11 ed.). Jakarta: Rineka Cipta.

Boy. (2009, 06 07). Kecerdasan Spiritual dan Pengaruhnya terhadap Kinerja Karyawan. Retrieved 01 20, 2017, from Badrudin's Blog: www.badrudin69.wordpress.com/2009/06/07/kecerdasan-spiritual-danpengaruhnya-terhadap-kinerja-karyawan.html

Class, N. (2010). Kumpulan Kajian Jurnal . Makassar: UMI.

Duta, A. (2010, 02 18). Ciri Kecerdasan Sosial. Retrieved 08 20, 2016, from Ilmu Psikologi Bimbingan Konseling: www.ilmupsikologi.wordpress.com/2010/02/08/ciri-kecerdasan-sosial.html

Keith, D., \& Newstrom, J. W. (1990). Human Behavior at Work, Terjemahan. Jakarta: Erlangga.

Rivai, V. (2005). Manajemen Sumber Daya Manusia untuk Perusahaan. Jakarta: Raja Grafindo Persada.

Sutrisno, E. (Manajemen Sumber Daya Manusia ). 2010. Jakarta: Kencana Teredana Group. 